\title{
Chemical composition, mineral content and cholesterol levels of some regular and reduced-fat white brined cheeses and strained yogurt (Labneh)
}

\author{
Dayana Abou Jaoude ${ }^{1}$, Ammar Olabi ${ }^{1}$, Nour El Ouyoun NajM ${ }^{1}$, Amal Malek ${ }^{1}$, \\ Carol SAADEH ${ }^{1}$, Elias BAYdOUN ${ }^{2}$, Imad ToufeILI ${ }^{1 *}$ \\ ${ }^{1}$ Department of Nutrition and Food Sciences, Faculty of Agricultural and Food Sciences, \\ American University of Beirut, Riad El Solh 1107 2020, Beirut, Lebanon \\ ${ }^{2}$ Department of Biology, Faculty of Arts and Sciences, American University of Beirut,
} Riad El Solh 1107 2020, Beirut, Lebanon

Received 13 November 2009 - Revised 11 February 2010 - Accepted 9 March 2010

Published online 18 June 2010

\begin{abstract}
White brined cheeses and strained yogurt (Labneh) are the most popular dairy products in the Eastern Mediterranean. However, scant data are available on the nutrient profiles of these products. In the present work, 38 samples of regular and reduced-fat varieties of four white brined cheeses (Akkawi, Halloumi, Double Crème and Braided) and Labneh, produced from cow's milk, were analyzed for basic nutrients (water, protein, fat, ash and lactose), cholesterol and selected minerals $(\mathrm{Na}, \mathrm{Ca}, \mathrm{K}, \mathrm{Mg}, \mathrm{P}$ and $\mathrm{Zn}$ ). The moisture contents of Labneh $\left(78.6 \mathrm{~g} \cdot 100 \mathrm{~g}^{-1}\right)$ and Double Crème $\left(60.3 \mathrm{~g} \cdot 100 \mathrm{~g}^{-1}\right)$ were higher than those of Akkawi, Halloumi and Braided cheeses $\left(46.6-55.1 \mathrm{~g} \cdot 100 \mathrm{~g}^{-1}\right)$. The fat content of full-fat Labneh was $8.8 \mathrm{~g} \cdot 100 \mathrm{~g}^{-1}$ while the full-fat brined cheeses contained fat levels between 18.3 and $23.9 \mathrm{~g} \cdot 100 \mathrm{~g}^{-1}$. Protein contents ranged between 8.9 and $24.8 \mathrm{~g} \cdot 100 \mathrm{~g}^{-1}$. Cholesterol strongly correlated with fat content and an increase in cholesterol/fat ratios was observed with decreasing fat levels. Sodium contents ranged between 151 and $5012 \mathrm{mg} \cdot 100 \mathrm{~g}^{-1}$ while Ca levels ranged between 43 and $921 \mathrm{mg} \cdot 100 \mathrm{~g}^{-}$. The moisture contents indicated that Double Crème was a soft cheese while Akkawi, Halloumi and Braided cheeses were firm/semi-hard cheeses. The fat levels in dry matter (FDM) revealed that only full-fat Double Crème cheese with a FDM of 48 can be classified as full-fat while the other cheeses can be classified as medium fat, partially skimmed or skim. These data will be of use to dairy scientists and technologists, dietitians and bodies concerned with promoting healthier dietary practices.
\end{abstract}

brined cheese / Labneh / composition / minerals / cholesterol

\begin{abstract}
摘要 - 常规和低脂白卤干酪及浓缩酸奶 (Labneh) 中化学成分矿物元素和胆固醇含量。 白甾干酪和浓缩酸奶是 (Labneh) 是地中海东部地区最普遍的乳制品。但是缺乏这些产 品营养方面的数据。本研究中, 在四种白卤干酪中 (常规和低脂干酪) 中取 38 个样品 (Akkawi, Halloumi, Double Crème 和 Braided) 以及用牛奶制作的浓缩酸奶 (Labneh), 分析了这些样品最基本的营养成分 (水分、蛋白、脂肪、灰分、乳糖)、胆固醇及一些元 素 $(\mathrm{Na}, \mathrm{Ca}, \mathrm{K}, \mathrm{Mg}, \mathrm{P}, \mathrm{Zn})$ 。 Labneh $\left(78.6 \mathrm{~g} \cdot 100 \mathrm{~g}^{-1}\right)$ 和 Double Crème $\left(60.3 \mathrm{~g} \cdot 100 \mathrm{~g}^{-1}\right)$ 的
\end{abstract}

*Corresponding author (通讯作者): toufeili@aub.edu.lb 
水分含量显著地高于 Akkawi，Halloumi 和 Braided 干酪 (46.6-55.1 g.100 g $\mathrm{g}^{-1}$ )。全脂 Labneh 中脂肪含量为 $8.8 \mathrm{~g} \cdot 100 \mathrm{~g}^{-1}$, 而全脂的盐卤干酪中脂肪含量在 18.3 和 $23.9 \mathrm{~g} \cdot 100 \mathrm{~g}^{-1}$ 。蛋 白质含量在 8.9 和 $24.8 \mathrm{~g} \cdot 100 \mathrm{~g}^{-1}$ 。胆固醇的含量与脂肪含量呈正相关, 并且随着脂肪量的 降低, 可以观察到明显的胆固醇/脂肪的比例在增加。 $\mathrm{Na}$ 含量在 $151 \sim 5012 \mathrm{mg} \cdot 100 \mathrm{~g}^{-1}$, 而 $\mathrm{Ca}$ 的含量在 $43 \sim 921 \mathrm{mg} \cdot 100 \mathrm{~g}^{-1}$ 。 水分含量的测定结果表明 Double Crème 是软质干酪, 而 Akkawi、Halloumi 和 Braided 是硬质/半硬质干酪。干物质中脂肪含量的测定结果表 明只有全脂的 Double Crème (干物质为 48) 才能分类为全脂干酪, 而其他干酪只能分类为 中脂、部分脱脂和脱脂干酪。本研究的数据将有助于乳品科技人员、营养学家以及关注 食品健康的消费者认识这类干酪的营养特性。

\section{盐卤干酪 / Labneh / 组成 / 矿物元素 / 胆固醇}

Résumé - Composition chimique et teneurs en minéraux et en cholestérol de fromages frais en saumure et de lait caillé égoutté (Labneh) à teneur normale ou réduite en matière grasse. Les fromages frais en saumure et le Labneh (lait caillé égoutté) sont les produits laitiers les plus populaires dans les pays situés à l'est du bassin méditerranéen. Cependant de rares données sont disponibles sur les profils nutritionnels de ces produits. Dans cette étude, 38 échantillons de 4 types de fromages frais en saumure (Akkawi, Halloumi, Double Crème et Braided) et de Labneh, à teneur normale ou réduite en matière grasse, produits à partir de lait de vache, ont été analysés pour leurs teneurs en nutriments basiques (eau, protéines, lipides, cendres, lactose), cholestérol et certains minéraux $(\mathrm{Na}, \mathrm{Ca}, \mathrm{K}, \mathrm{Mg}, \mathrm{P}, \mathrm{Zn})$. La teneur en matière grasse des Labneh " gras " était de $8,8 \mathrm{~g} \cdot 100 \mathrm{~g}^{-1}$ tandis que les fromages frais en saumure " gras » présentaient des teneurs en matière grasse de 18,3 à $23,9 \mathrm{~g} \cdot 100 \mathrm{~g}^{-1}$. Le cholestérol était fortement corrélé avec la teneur en matière grasse et une augmentation des ratios cholestérol/matière grasse était observée avec la réduction des niveaux de matière grasse. Les teneurs en sodium variaient entre 151 et $5012 \mathrm{mg} \cdot 100 \mathrm{~g}^{-1}$ alors que les teneurs en calcium allaient de 43 à $921 \mathrm{mg} \cdot 100 \mathrm{~g}^{-1}$. Les teneurs en humidité indiquaient que le Double Crème est un fromage à pâte molle, alors que l'Akkawi, l'Halloumi et le Braided sont des fromages fermes/à pâte demi-dure. Les niveaux de matière grasse sur extrait sec $(\mathrm{G} / \mathrm{S})$ montraient que seul le Double Crème à teneur non réduite en matière grasse peut être classé en fromage « gras » avec un G/S égal à 48, alors que les autres fromages peuvent être classés en " moyennement gras », " partiellement maigre », ou « maigre ». Ces données seront utiles aux scientifiques et technologues du domaine laitier, aux diététiciens, et aux parties concernées par la promotion de pratiques alimentaires plus saines.

\section{fromage en saumure / Labneh / composition / minéraux / cholesterol}

\section{INTRODUCTION}

The conversion of milk into cheese, and storage of the product in brine, has been practiced in the Eastern Mediterranean countries for thousands of years. The process is a practical means for preserving milk nutrients in a form that can be safely stored for extended periods of time at the high ambient temperatures in the region [16]. White brined cheeses, which continue to be the typical and most consumed group of cheeses in the Eastern Mediterranean region and in some neighboring countries, were traditionally produced from goat's and sheep's milk [1]. Nowadays, large-scale dairy processors are using the more readily available cow's milk to meet the growing demand for these cheeses in the Middle East and export markets [16]. Moreover, growing consumer demand for low-fat/low-salt products, driven by higher awareness of the perceived health risks associated with the consumption of diets high in fat and salt, has led to an increase in the production of low-fat/low-salt analogs of white brined cheeses.

A number of white brined cheese varieties differing in texture and composition 
are consumed in the Eastern Mediterranean countries with the range including Halloumi, Akkawi, Braided (mujaddal) and Double Crème. Concentrated yogurt, commonly known as Labneh in the Middle East and as strained yogurt in Europe, is also widely consumed in the region. Labneh evolved as a means to prolong the shelf life of yogurt by straining away part of its whey in cloth bags (traditional method) or by modern procedures utilizing ultrafiltration and centrifugation [13].

The great majority of white brined cheeses are rennet-coagulated and brinesalted. During the manufacture of Akkawi cheese, the molded curd is pressed to expel even more whey and stored in brine. For Halloumi cheese, the pressed curd is boiled in the cheese whey prior to storage in brine. In the production of Double Crème cheese, the whey obtained during cheese making is mixed with full-fat milk and/or cream and heated at $90-95^{\circ} \mathrm{C}$ in the presence of citric acid and the flocculate that forms at the surface is skimmed off, placed in cheesecloth, pressed for $\sim 1 \mathrm{~h}$ and stored in brine. Finally, for Braided cheese, the curd is left to acidify ( $\mathrm{pH} \sim 5.2)$ and then stretched and shaped into a loop, at $70-75^{\circ} \mathrm{C}$, which is finally split into strands to form the braid of the final cheese [16].

White brined cheeses make an important contribution to the overall nutrient content of the Mediterranean diet which highlights the need for data on the composition of these cheeses. The literature on basic nutrient and mineral element composition of Mediterranean cheeses is rather scarce and limited to Turkish and Greek varieties $[2,4,7,9-11]$. The aim of this work is to report on the macronutrient and mineral composition and the cholesterol contents of four regular and reduced-fat white brined cheeses (Akkawi, Halloumi, Double Crème and Braided) and Labneh that are heavily consumed in the Mediterranean region.

\section{MATERIALS AND METHODS}

\subsection{Samples}

A total of 38 samples of commercially packed Labneh and cheese samples from the leading brands marketed in Lebanon were analyzed and included Labneh (4 full-fat samples, 3 low-fat samples and 4 fat-free samples), Akkawi cheese (4 fullfat, 4 low-fat and 1 fat-free), Halloumi cheese (4 full-fat, 3 low-fat and 1 fat-free), Double Crème cheese ( 4 full-fat and 1 fatfree) and Braided cheese (3 full-fat and 2 low-fat). Ten packages $(\sim 300 \mathrm{~g})$ from each brand and product category were sampled and bulked according to AOAC Official Methods 920.122 and 955.30 [3] to prepare representative samples; the prepared samples were wrapped in plastic films and placed in plastic containers at $-20{ }^{\circ} \mathrm{C}$ until analyzed.

\subsection{Chemical analyses}

Water content was determined by drying on a water bath and then in an oven at $130 \pm 1{ }^{\circ} \mathrm{C}$ for $75 \mathrm{~min}$ according to AOAC 2000, Official Method 948.12 [3].

Fat content was determined by extraction with hexane and diethyl ether after digestion with $\mathrm{HCl}$ according to AOAC 2000, Official Method 933.05 [3].

Crude protein $(\mathrm{N} \times 6.38)$ was determined by the Kjeldahl procedure according to AOAC 2000, Official Method 920.125 [3] using a Labconco Rapidstill II (Missouri, USA) digestion and distillation apparatus.

Lactose was determined by enzymatic hydrolysis to galactose and glucose and oxidation of the liberated galactose to galactonic acid by galactose dehydrogenase in the presence of $\mathrm{NAD}^{+}$and measuring the amount of $\mathrm{NADH}, \mathrm{H}^{+}$produced spectrophotometrically at $340 \mathrm{~nm}$ according to AOAC 2000, Official Method 984.15 [3]. Lactose determination was carried out using 
a kit from Megazyme International Ireland Ltd. (Wicklow, Ireland).

Cholesterol was determined by saponification of the fat extracts with methanolic $\mathrm{KOH}$, extraction of the non-saponifiable fraction with ether/light petroleum, evaporation of the ether/light petroleum at $45{ }^{\circ} \mathrm{C}$ and dissolving the residue in propan-2-ol. The cholesterol content of the solution was determined by oxidation with cholesterol oxidase, conversion of methanol to formaldehyde by the hydrogen peroxide produced, complexing of formaldehyde with acetylacetone and measuring the absorption of the resulting yellow chromogen at $405 \mathrm{~nm}$ [15]. Cholesterol determination was carried out using a kit from Boehringer Mannheim/ R-Biopharm (Darmstadt, Germany).

Phosphorus was determined colorimetrically according to AOAC 2000, Official Method 991.25 [3]. Calcium, magnesium and zinc were determined by atomic absorption (SOLAAR Atomic Absorption Spectrophotometer, Thermo Labsystems, MA, USA) and sodium and potassium by flame photometry (AFP-100 Automatic Flame Photometer, Sedico Ltd., Nicosia, Cyprus) according to AOAC 2000, Official Methods 999.1 and 990.23 [3].

The veracity of the determinations was assayed by analysis of certified whole milk powder (SRM 8435; National Institute of Standards and Technology, Maryland, USA). Determinations were carried out in triplicate.

\section{RESULTS AND DISCUSSION}

The analytical data (Tab. I) indicated that Akkawi, Halloumi and Braided (mujaddal) are firm/semi-hard cheeses while Double Crème is a soft cheese according to the classification scheme of the Codex Alimentarius based on percentage moisture on a fat-free basis (MFFB) (firm/semi-hard 54-69\% MFFB; soft > 69\% MFFB) [5]. Labneh, Akkawi, Halloumi and Braided (mujaddal) cheeses exhibited fat-in-dry matter (FDM) contents $<44 \%$ while full-fat Double Crème had a mean FDM of $48 \pm 10.4 \%$. According to the Codex Alimentarius' classification [5] all the commercially designated full-fat samples, analyzed in the present work, will be classed as medium fat with the exception of Double Crème which is considered as full-fat. The cheeses and Labneh contained low levels of lactose $\left(0.05-1.1 \mathrm{~g} \cdot 100 \mathrm{~g}^{-1}\right)$ (Tab. I) presumably due to its expulsion from the cheese and yogurt during whey draining and its utilization by the starter used in the preparation of yogurt.

The composition of the cheeses also indicated that moisture content was inversely related to the fat content $(r=-0.821$, $P<0.01)$ and to the sodium content $(r=-0.540, P<0.01)$, as reported for Cheddar [14], and to protein content $(r=-0.763, P<0.01)$ as observed for Turkish brined cheeses [10]. Furthermore, the FDM contents of low-fat Akkawi, low-fat Halloumi and low-fat Double Crème (data not shown) exceeded the range of $10-25 \mathrm{~g} \cdot 100 \mathrm{~g}^{-1}$ reported for low-fat Akkawi and Halloumi and the range of $10-33 \mathrm{~g} \cdot 100 \mathrm{~g}^{-1}$ for low-fat Double Crème [16].

The cholesterol contents were highly correlated with the fat levels $(r=0.925$, $P<0.01$ ) (Tab. I). Furthermore, Labneh exhibited lower cholesterol levels $\left(6.6-29.5 \mathrm{mg} \cdot 100 \mathrm{~g}^{-1}\right)$ than the brined cheeses (Tab. I). The cholesterol levels of Akkawi, Halloumi, Double Crème and Braided cheeses were comparable to those reported for Greek [2] and Turkish [7] brined cheese varieties. An increase in the cholesterol/fat ratios was observed with decreasing fat levels in the different cheeses (Tab. I). Cholesterol is found inside the fat globules and in the milk-fat-globule membrane, with small fat globules exhibiting higher cholesterol/fat ratios due to their higher surface area [12]. The increase in cholesterol/fat ratios with decreasing fat contents is presumably due to the rupture 
Table I. Basic nutrients and cholesterol contents of white brined cheeses.

\begin{tabular}{|c|c|c|c|c|c|c|}
\hline $\begin{array}{l}\text { Cheese variety } \\
\text { and commercial } \\
\text { classification }\end{array}$ & $\begin{array}{l}\text { Moisture } \\
\left(\mathrm{g} \cdot 100 \mathrm{~g}^{-1}\right)\end{array}$ & $\begin{array}{c}\text { Fat } \\
\left(\mathrm{g} \cdot 100 \mathrm{~g}^{-1}\right)\end{array}$ & $\begin{array}{l}\text { Protein } \\
\left(\mathrm{g} \cdot 100 \mathrm{~g}^{-1}\right)\end{array}$ & $\begin{array}{c}\text { Ash } \\
\left(\mathrm{g} \cdot 100 \mathrm{~g}^{-1}\right)\end{array}$ & $\begin{array}{l}\text { Lactose } \\
\left(\mathrm{g} \cdot 100 \mathrm{~g}^{-1}\right)\end{array}$ & $\begin{array}{l}\text { Cholesterol } \\
\left(\mathrm{mg} \cdot 100 \mathrm{~g}^{-1}\right)\end{array}$ \\
\hline \multicolumn{7}{|l|}{ Akkawi } \\
\hline $\begin{array}{l}\text { Full-fat } \\
n=4\end{array}$ & $\begin{array}{c}54.3 \pm 3.0^{\mathrm{a}} \\
(50.0-57.0)^{\mathrm{b}}\end{array}$ & $\begin{array}{c}19.3 \pm 2.1 \\
(17.5-22.3)\end{array}$ & $\begin{array}{c}17.6 \pm 1.5 \\
(16.2-19.3)\end{array}$ & $\begin{array}{l}5.1 \pm 0.6 \\
(4.4-5.8)\end{array}$ & $\begin{array}{l}0.8 \pm 0.2 \\
(0.5-1.0)\end{array}$ & $\begin{array}{c}59.5 \pm 1.8 \\
(56.9-60.9)\end{array}$ \\
\hline Low-fat & $56.1 \pm 1.3$ & $14.5 \pm 1.9$ & $16.9 \pm 0.6$ & $5.1 \pm 1.2$ & $1.1 \pm 0.1$ & $60.3 \pm 8.2$ \\
\hline$n=4$ & $(54.2-57.2)$ & $(11.8-16.3)$ & $(16.2-17.5)$ & $(4.2-6.9)$ & $(1.0-1.2)$ & $(48.7-66.5)$ \\
\hline $\begin{array}{l}\text { Fat-free } \\
n=1\end{array}$ & 59.2 & 3.4 & 25.3 & 3.0 & 0.7 & 25.1 \\
\hline \multicolumn{7}{|l|}{ Halloumi } \\
\hline $\begin{array}{l}\text { Full-fat } \\
n=4\end{array}$ & $\begin{array}{c}48.4 \pm 1.7 \\
(45.9-49.7)\end{array}$ & $\begin{array}{c}22.7 \pm 0.9 \\
(21.8-23.9)\end{array}$ & $\begin{array}{l}22.8 \pm 1.8 \\
(21.1-25.4)\end{array}$ & $\begin{array}{l}5.0 \pm 0.3 \\
(4.6-5.3)\end{array}$ & $\begin{array}{l}0.9 \pm 0.2 \\
(0.7-1.2)\end{array}$ & $\begin{array}{c}69.3 \pm 4.5 \\
(64.6-73.8)\end{array}$ \\
\hline $\begin{array}{l}\text { Low-fat } \\
n=3\end{array}$ & $\begin{array}{c}53.6 \pm 3.2 \\
(50.7-57.0)\end{array}$ & $\begin{array}{c}17.6 \pm 5.8 \\
(11.0-21.5)\end{array}$ & $\begin{array}{c}25.8 \pm 3.6 \\
(22.1-29.3)\end{array}$ & $\begin{array}{l}5.0 \pm 1.0 \\
(4.1-6.1)\end{array}$ & $\begin{array}{l}0.7 \pm 0.2 \\
(0.5-0.9)\end{array}$ & $\begin{array}{l}67.9 \pm 17.5 \\
(47.9-79.6)\end{array}$ \\
\hline $\begin{array}{l}\text { Fat-free } \\
n=1\end{array}$ & 59.2 & 3.3 & 32 & 3.0 & 1.2 & 33.4 \\
\hline \multicolumn{7}{|l|}{ Double Crème } \\
\hline $\begin{array}{l}\text { Full-fat } \\
n=4\end{array}$ & $\begin{array}{c}60.3 \pm 4.7 \\
(55.7-66.9)\end{array}$ & $\begin{array}{c}19.4 \pm 6.0 \\
(10.9-24.9)\end{array}$ & $\begin{array}{c}10.9 \pm 0.4 \\
(10.3-11.2)\end{array}$ & $\begin{array}{l}3.3 \pm 1.2 \\
(2.0-4.4)\end{array}$ & $\begin{array}{l}1.1 \pm 0.2 \\
(0.7-1.2)\end{array}$ & $\begin{array}{c}81.5 \pm 20.0 \\
(56.2-104.9)\end{array}$ \\
\hline $\begin{array}{l}\text { Fat-free } \\
n=1\end{array}$ & 69 & 2.6 & 19.7 & 2.2 & 0.9 & 35.9 \\
\hline \multicolumn{7}{|c|}{ Braided (mujaddal) } \\
\hline $\begin{array}{l}\text { Full-fat } \\
n=3\end{array}$ & $\begin{array}{c}46.6 \pm 3.1 \\
(43.8-49.9)\end{array}$ & $\begin{array}{c}19.3 \pm 1.0 \\
(18.4-20.4)\end{array}$ & $\begin{array}{l}23.6 \pm 2.8 \\
(21.2-26.7)\end{array}$ & $\begin{array}{l}9.4 \pm 1.4 \\
(8-10.8)\end{array}$ & $\begin{array}{l}0.3 \pm 0.1 \\
(0.2-0.4)\end{array}$ & $\begin{array}{c}56.1 \pm 6.2 \\
(49.6-62.1)\end{array}$ \\
\hline $\begin{array}{l}\text { Low-fat } \\
n=2\end{array}$ & $\begin{array}{c}53.1 \pm 2.4 \\
(51.4-54.8)\end{array}$ & $\begin{array}{c}8.9 \pm 4.4 \\
(5.9-12.1)\end{array}$ & $\begin{array}{c}21.2 \pm 0.4 \\
(20.9-21.5)\end{array}$ & $\begin{array}{c}13.1 \pm 2.8 \\
(11.1-15.1)\end{array}$ & $\begin{array}{c}0.4 \pm 0.2 \\
(0.25-0.47)\end{array}$ & $\begin{array}{c}31.5 \pm 8.2 \\
(25.8-37.3)\end{array}$ \\
\hline \multicolumn{7}{|c|}{ Strained yogurt (Labneh) } \\
\hline $\begin{array}{l}\text { Full-fat } \\
n=4\end{array}$ & $\begin{array}{c}78.6 \pm 2.0 \\
(75.8-80.3)\end{array}$ & $\begin{array}{c}8.8 \pm 1.8 \\
(7.1-10.9)\end{array}$ & $\begin{array}{l}8.9 \pm 0.7 \\
(8.2-9.6)\end{array}$ & $\begin{array}{l}1.0 \pm 0.1 \\
(0.9-1.2)\end{array}$ & $\begin{array}{c}0.05 \pm 0.1 \\
(0.0-0.2)\end{array}$ & $\begin{array}{c}29.5 \pm 4.1 \\
(24.3-34.0)\end{array}$ \\
\hline $\begin{array}{l}\text { Low-fat } \\
n=3\end{array}$ & $\begin{array}{c}79.2 \pm 1.7 \\
(77.2-80.2)\end{array}$ & $\begin{array}{l}4.3 \pm 0.3 \\
(4.0-4.6)\end{array}$ & $\begin{array}{l}10.0 \pm 0.8 \\
(9.3-10.8)\end{array}$ & $\begin{array}{l}1.0 \pm 0.2 \\
(0.9-1.2)\end{array}$ & $\begin{array}{c}0.2 \pm 0.0 \\
(0.2)\end{array}$ & $\begin{array}{c}18.8 \pm 1.8 \\
(17.1-20.7)\end{array}$ \\
\hline $\begin{array}{l}\text { Fat-free } \\
n=4\end{array}$ & $\begin{array}{c}85.8 \pm 1.5 \\
(84.6-87.7)\end{array}$ & $\begin{array}{l}0.6 \pm 0.6 \\
(0.1-1.4)\end{array}$ & $\begin{array}{l}10.1 \pm 1.2 \\
(9.1-11.7)\end{array}$ & $\begin{array}{l}0.9 \pm 0.1 \\
(0.7-1.0)\end{array}$ & $\begin{array}{l}0.7 \pm 0.6 \\
(0.0-1.5)\end{array}$ & $\begin{array}{c}6.6 \pm 5.3 \\
(3.3-14.5)\end{array}$ \\
\hline
\end{tabular}

${ }^{a}$ Mean value \pm standard deviation.

${ }^{\mathrm{b}}$ Range (minimum-maximum).

$n=$ number of samples.

of the large fat globules, and subsequent migration of cholesterol to the milk serum, and the retention of small fat globules during preparation of low/no-fat milk [12].

$\mathrm{Na}, \mathrm{Ca}, \mathrm{P}, \mathrm{K}$ and $\mathrm{Mg}$ were the major elements in all the cheeses and Labneh while
$\mathrm{Zn}$ was present at much lower levels (Tab. II). The concentration of $\mathrm{Na}$ was highest in all the cheeses with large differences in $\mathrm{Na}$ levels being noted between different brands of the same type of cheese. Double Crème had the lowest $\mathrm{Na}$ content 
Table II. Mineral and trace element contents $\left(\mathrm{mg} \cdot 100 \mathrm{~g}^{-1}\right)$ of white brined cheeses.

\begin{tabular}{|c|c|c|c|c|c|c|}
\hline $\begin{array}{l}\text { Cheese variety } \\
\text { and commercial } \\
\text { classification }\end{array}$ & $\mathrm{K}$ & $\mathrm{P}$ & $\mathrm{Na}$ & $\mathrm{Mg}$ & $\mathrm{Ca}$ & $\mathrm{Zn}$ \\
\hline \multicolumn{7}{|l|}{ Akkawi } \\
\hline $\begin{array}{l}\text { Full-fat } \\
n=4\end{array}$ & $\begin{array}{l}55 \pm 20^{\mathrm{a}} \\
(41-86)^{\mathrm{b}}\end{array}$ & $\begin{array}{c}432 \pm 52 \\
(382-500)\end{array}$ & $\begin{array}{l}1418 \pm 470 \\
(835-1939)\end{array}$ & $\begin{array}{c}34 \pm 8 \\
(24-43)\end{array}$ & $\begin{array}{c}445 \pm 55 \\
(397-515)\end{array}$ & $\begin{array}{l}4 \pm 0 \\
(3-4)\end{array}$ \\
\hline Low-fat & $97 \pm 47$ & $422 \pm 47$ & $1195 \pm 541$ & $49 \pm 13$ & $485 \pm 60$ & $4 \pm 0$ \\
\hline$n=4$ & $(53-159)$ & $(382-490)$ & $(777-1965)$ & $(41-69)$ & $(430-568)$ & $(3-4)$ \\
\hline $\begin{array}{l}\text { Fat-free } \\
n=1\end{array}$ & 87 & 522 & 159 & 29 & 521 & 5 \\
\hline \multicolumn{7}{|l|}{ Halloumi } \\
\hline $\begin{array}{l}\text { Full-fat } \\
n=4\end{array}$ & $\begin{array}{l}56 \pm 23 \\
(40-90)\end{array}$ & $\begin{array}{c}443 \pm 23 \\
(426-477)\end{array}$ & $\begin{array}{l}1039 \pm 121 \\
(939-1194)\end{array}$ & $\begin{array}{l}72 \pm 12 \\
(55-84)\end{array}$ & $\begin{array}{c}750 \pm 41 \\
(702-799)\end{array}$ & $\begin{array}{r}4 \pm 0 \\
(4-45)\end{array}$ \\
\hline $\begin{array}{l}\text { Low-fat } \\
n=3\end{array}$ & $\begin{array}{l}51 \pm 10 \\
(40-58)\end{array}$ & $\begin{array}{c}463 \pm 74 \\
(394-541)\end{array}$ & $\begin{array}{l}1019 \pm 339 \\
(652-1320)\end{array}$ & $\begin{array}{l}65 \pm 26 \\
(35-86)\end{array}$ & $\begin{array}{c}757 \pm 93 \\
(650-822)\end{array}$ & $\begin{array}{l}4 \pm 0 \\
(4-5)\end{array}$ \\
\hline $\begin{array}{l}\text { Fat-free } \\
n=1\end{array}$ & 157 & 622 & 54 & 53 & 921 & 5 \\
\hline \multicolumn{7}{|l|}{ Double Crème } \\
\hline $\begin{array}{l}\text { Full-fat } \\
n=4\end{array}$ & $\begin{array}{l}57 \pm 19 \\
(34-81)\end{array}$ & $\begin{array}{c}262 \pm 93 \\
(126-322)\end{array}$ & $\begin{array}{c}995 \pm 217 \\
(736-1258)\end{array}$ & $\begin{array}{c}40 \pm 9 \\
(30-52)\end{array}$ & $\begin{array}{l}378 \pm 123 \\
(197-463)\end{array}$ & $\begin{array}{l}2 \pm 0 \\
(2-3)\end{array}$ \\
\hline $\begin{array}{l}\text { No-fat } \\
n=1\end{array}$ & 109 & 227 & 118 & 18 & 274 & 3 \\
\hline \multicolumn{7}{|c|}{ Braided (mujaddal) } \\
\hline $\begin{array}{l}\text { Full-fat } \\
n=3\end{array}$ & $\begin{array}{l}60 \pm 31 \\
(41-95)\end{array}$ & $\begin{array}{c}333 \pm 41 \\
(286-358)\end{array}$ & $\begin{array}{c}2796 \pm 621 \\
(2080-3176)\end{array}$ & $\begin{array}{l}83 \pm 16 \\
(65-94)\end{array}$ & $\begin{array}{c}320 \pm 26 \\
(290-337)\end{array}$ & $\begin{array}{l}5 \pm 1 \\
(3-6)\end{array}$ \\
\hline $\begin{array}{l}\text { Low-fat } \\
n=2\end{array}$ & $\begin{array}{c}53 \pm 3 \\
(51-55)\end{array}$ & $\begin{array}{l}478 \pm 121 \\
(392-563)\end{array}$ & $\begin{array}{l}5012 \pm 1752 \\
(3773-6250)\end{array}$ & $\begin{array}{c}170 \pm 203 \\
(27-314)\end{array}$ & $\begin{array}{l}524 \pm 196 \\
(386-663)\end{array}$ & $\begin{array}{r}9 \pm 8 \\
(3-15)\end{array}$ \\
\hline \multicolumn{7}{|c|}{ Strained yogurt (Labneh) } \\
\hline $\begin{array}{l}\text { Full-fat } \\
n=4\end{array}$ & $\begin{array}{c}89 \pm 8 \\
(79-100)\end{array}$ & $\begin{array}{c}140 \pm 6 \\
(130-146)\end{array}$ & $\begin{array}{c}199 \pm 28 \\
(166-237)\end{array}$ & $\begin{array}{c}17 \pm 3 \\
(13-21)\end{array}$ & $\begin{array}{c}94 \pm 5 \\
(87-99)\end{array}$ & $\begin{array}{l}1 \pm 0 \\
(1-2)\end{array}$ \\
\hline $\begin{array}{l}\text { Low-fat } \\
n=3\end{array}$ & $\begin{array}{c}98 \pm 11 \\
(89-110)\end{array}$ & $\begin{array}{c}148 \pm 6 \\
(141-152)\end{array}$ & $\begin{array}{l}255 \pm 20 \\
(242-278)\end{array}$ & $\begin{array}{l}31 \pm 8 \\
(25-40)\end{array}$ & $\begin{array}{c}43 \pm 2 \\
(42-45)\end{array}$ & $\begin{array}{l}1 \pm 0 \\
(1-1)\end{array}$ \\
\hline $\begin{array}{l}\text { Fat-free } \\
n=4\end{array}$ & $\begin{array}{c}96 \pm 24 \\
(69-122)\end{array}$ & $\begin{array}{c}135 \pm 14 \\
(124-154)\end{array}$ & $\begin{array}{l}151 \pm 91 \\
(73-257)\end{array}$ & $\begin{array}{c}22 \pm 4 \\
(18-28)\end{array}$ & $\begin{array}{c}94 \pm 8 \\
(86-104)\end{array}$ & $\begin{array}{l}1 \pm 0 \\
(1-2)\end{array}$ \\
\hline
\end{tabular}

${ }^{\text {a }}$ Mean value \pm standard deviation.

b Range (minimum-maximum).

$n=$ number of samples.

among brined cheeses with a range of 736-1258 mg.100 $\mathrm{g}^{-1}$, whereas Braided cheeses exhibited the highest and most variable Na levels with ranges of 2080-3176 and $3773-6250 \mathrm{mg} \cdot 100 \mathrm{~g}^{-1}$ found in the full-fat and low-fat products, respectively.
The high and variable levels of $\mathrm{Na}$ observed for the different white brined cheeses are chiefly due to the addition of salt during processing and storage in brine [10] and the consumers' demands for low $\mathrm{Na}$ variants of brined cheeses. The lower levels 
of $\mathrm{Na}$ observed for Labneh (Tab. II) are presumably due to the shorter shelf life anticipated for this type of product ( $\sim 2$ weeks at refrigeration temperatures), and therefore its lower dependence on the preservative effect of $\mathrm{NaCl}$, compared with those of the brined cheeses ( 6-12 months). The Na levels of the brined cheeses analyzed in the present work were alarmingly high with a $35 \mathrm{~g}$ serving of low-fat Braided cheese having a sodium load ( $2200 \mathrm{mg}$ ) higher than the Daily Reference Value for $\mathrm{Na}$ set at $1500 \mathrm{mg}$ [8]. Calcium was the second major element in the white brined cheeses and was highest in the no-fat Halloumi cheese reaching a level of $921 \mathrm{mg} \cdot 100 \mathrm{~g}^{-1}$. The mineral profiles of Halloumi and Labneh were comparable to the ranges previously reported for these products [6].

\section{CONCLUSION}

Basic nutrient composition analyses revealed that Akkawi, Halloumi and Braided cheeses are firm/semi-hard while Double Crème cheese is a soft cheese according to the classification scheme of the Codex Alimentarius based on percentage MFFB. Apart from full-fat Double Crème cheese, which is classified as fullfat on MFFB, the other brined cheeses which are commercially designated as fullfat are classed as medium fat. Sodium was present at the highest and most variable levels in the analyzed cheeses and at extremely high concentrations in some varieties. The use of such high levels of salt in the processing of brined cheeses is not justifiable, especially with the increasing institution of quality systems in dairy processing and the spread of refrigeration facilities in the Eastern Mediterranean countries.

The data presented in this work on the composition of common white brined cheeses and Labneh consumed in the Eastern
Mediterranean provide background information on the nutrient profiles of these dairy products and should be of use in dietary planning, to international agencies in policy planning and intervention strategies, and to manufacturers concerned with producing cheeses containing lower levels of salt, fat and cholesterol.

\section{REFERENCES}

[1] Alichanidis E., Polychroniadou A., Characteristics of major traditional regional cheese varieties of East-Mediterranean countries: a review, Dairy Sci. Technol. 88 (2008) 495-510.

[2] Andrikopoulos N.K., Kalogeropoulos N., Zerva A., Zerva U., Hassapidou M., Kapoulas V.M., Evaluation of cholesterol and other nutrient parameters of Greek cheese varieties, J. Food Compos. Anal. 16 (2003) 155-167.

[3] AOAC, Official Methods of Analysis of AOAC International, vol. 2, 17th edn., Association of Official Analytical Chemists, Maryland, USA, 2000.

[4] Celik S., Turkoglu H., Ripening of traditional Örgü cheese manufactured with raw or pasteurized milk: Composition and biochemical properties, Int. J. Dairy Technol. 60 (2007) 253-258.

[5] Codex Alimentarius, Milk and Milk Products, 1st edn., FAO, Rome, Italy, 2007.

[6] Dashti B., Al-Awadi F., Al-Kandari R., Ali A., Al-Otaibi J., Macro- and microelements contents of 32 Kuwaiti composite dishes, Food Chem. 85 (2004) 331-337.

[7] Donmez M., Seckin A.K., Sagdic O., Simsek B., Chemical characteristics, fatty acid compositions, conjugated linoleic acid contents and cholesterol levels of some traditional Turkish cheeses, Int. J. Food Sci. Nutr. 56 (2005) 157-163.

[8] Institute of Medicine, Dietary reference intakes for water, potassium, sodium, chloride, and sulfate, The National Academies Press, Washington, USA, 2005.

[9] Mallatou H., Pappa E.C., Comparison of the characteristics of teleme cheese made from ewe's, goat's and cow's milk or a mixture of ewe's and goat's milk, Int. J. Dairy Technol. 58 (2005) 158-163. 
[10] Mendil D., Mineral and trace metal levels in some cheese collected from Turkey, Food Chem. 96 (2006) 532-537.

[11] Merdivan M., Yilmaza E., Hamamcia C., Aygunc R.S., Basic nutrients and element contents of white cheese of diyarbakir in Turkey, Food Chem. 87 (2004) 163-171.

[12] Molkentin J., Cholesterol content and lipid composition of low fat dairy products, Eur. Food Res. Technol. 223 (2006) 253-260.

[13] Nsabimana C., Jiang B., Kossah R., Manufacturing, properties and shelf life of Labneh: A review, Int. J. Dairy Technol. 58 (2005) 129-137.
[14] Smith L., Schonfelst H., De Beer W., Smith M., The influence of factory and region on the composition of South African Cheddar and Gouda cheese, J. Food Compos. Anal. 14 (2001) 177-198.

[15] Stähler F., Gruber W., Stinshoff K., Röschlau P., Eine praxisgerechte enzymatische Cholesterin-Bestimmung [A practical enzymatic cholesterol determination], Med. Lab. 30 (1977) 29-37.

[16] Toufeili I., Ozer B., Brined cheeses from the Middle East and Turkey, in: Tamime A.Y. (Ed.), Brined cheeses, Blackwell Publishing Ltd., Oxford, UK, 2006, pp. 188-210. 